\title{
Immunostimulatory activity of brown seaweed-derived fucoidans at different molecular weights and purity levels towards white spot syndrome virus (WSSV) in shrimp Litopenaeus vannamei
}

\author{
Ellya Sinurat ${ }^{1,2^{*}}$, Endang Saepudin ${ }^{2}$, Rosmawaty peranginangin ${ }^{1}$, Sumi Hudiyono ${ }^{2}$ \\ ${ }^{1}$ Research and Development Center for Marine and Fisheries Product Processing and Biotechnology. ${ }^{2}$ Department of Chemistry, Faculty of Sciences, \\ Universitas Indonesia.
}

\begin{tabular}{l} 
ARTICLE INFO \\
\hline Article history: \\
Received on: $17 / 03 / 2016$ \\
Revised on: 05/05/2016 \\
Accepted on: 02/06/2016 \\
Available online: $29 / 10 / 2016$ \\
\hline Key words: \\
Fucoidan, Immunostimulant, \\
WSSV, Molecule weight, \\
Shrimp.
\end{tabular}

\begin{abstract}
Fucoidan used as immunostimulant is commonly in the crude form. In this study, we investigated the effect of fucoidan in both crude and purified forms in their immunostimulatory activity. In addition, we studied the effect of low- and high-molecular weight fucoidan as hydrolysis products toward immunostimulatory activity. Four kinds of fucoidan were assayed for immunostimulant activity on the shrimp Litopenaeus vannamei. The parameters observed in the assay includes the mortality number, haemocyte, gene-related immunity (phenoloxidase, superoxide dismutase and transglutaminase) in the shrimps infected with viral WSSV. The assay results showed that pure fucoidan exhibited higher activity compared with that of crude fucoidan. Sulfate and carbohydrate content of HMW fucoidan are $7.8 \%$ and $82.54 \%$ with an estimated molecular weight of 8.28 $\mathrm{x} 10^{4}$ Dalton, and low molecular weight (LMW) fucoidan has $1.2 \%$ and $65.23 \%$ with an estimated molecular weight of $7.53 \times 10^{4}$ Dalton. The transcriptional level of the immunity-related genes was found higher after feeding the infected shrimps with purified and HMW fucoidan. In particular, all of fucoidan forms increased the phenoloxidase gene transcription, suggesting that fucoidan have significant role in the production of phenoloxidase.
\end{abstract}

\section{INTRODUCTION}

White spot syndrome virus (WSSV) is one of the virulent pathogens and causes big economic losses to shrimp aquaculture (Flegel, 2011). Efforts to prevent outbreaks of WSSV in the cultivation method, include the bio-secured operating system, controlled environmental conditions and vaccination, the use of antimicrobial peptides, immunostimulants and RNA interference (RNAi) technology (Valerie et al., 2003). In general, most crustaceans have no immune system memory and only rely on innate immunity to protect themself against pathogen infection and other external factors that constantly threatens their lives (Sarathi et al., 2007). Research in the

* Corresponding Author

Ellya Sinurat, Research and Development Center for Marine and Fisheries Product Processing and Biotechnology Marine and Fisheries mail id:ellya_sinurat@yahoo.com immune response of shrimp has flourished because of its importance in aquaculture and the increasing number of pathogens that arise are found, which may affect an organism's defense system (Bachere et al., 2000). To fight these pathogens, the shrimp using a variety of specific immune mechanisms, including haemocytes mobilization (Johansson and Soderhall, 1989); prophenoloxidase cascade formation (Sritunyalucksana and Soderhall, 2000). The immune system of shrimp is intimately related to its blood (hemolymph), because it contains haemocytes involved in cell's defense mechanisms such as phagocytosis, lysis of foreign units and encapsulation (Soderhall and Smith, 1983; Soderhall and Cerenius, 1992; Fuhua and Jianhai, 2013; (Dechamag et al., 2006). Prophenoloxidase (proPO) system is an important defense mechanism in crustaceans. This system involves a complex molecular cascade triggered by components of the surface of immunostimulants. The zymogen proPO is converted to the active form, phenoloxidase (PO). 
After activation, PO subsequently initiates the molecular cascade and finally the formation of dark and insoluble melanin pigment. The parameters observed after fucoidan treatment on shrimp include: haemocyte (morphology, activation, cell size) and superoxide generation through proPO activation by haemocytes (Chen et al., 2014). Superoxide anions are the first products released during the respiratory burst $(\mathrm{RB})$, and their derivatives have a bactericidal activity (Munoz et al., 2000). The superoxide anion is scavenged by superoxide dismutase (SOD) to form oxygen and hydrogen peroxide that is subsequently scavenged by peroxidase and catalase in the presence of a reducing agent (Fridovich et al., 1995; Holmblad and Soderhall, 1999).

The use of immunostimulants is considered as a more environmentally friendly approach and has been proven to enhance the innate immunity of shrimps and their resistance against pathogens (Sirirustanaun et al., 2011; Takahashi et al., 1998; Chotigeat et al., 2004; Pholdaeng and Sunanta, 2010). A number of immunostimulants that have been used in aquaculture are from the class of polysaccharides derived from bacteria and fungi such as $\square$-glucan, lipopolysaccharide (LPS), peptidoglycan, Cynodon dactylon and herbal immunostimulant. In addition to that, there are also immunostimulants derived from seaweeds such as alginate, carrageenan, laminarin and fucoidan (Grassian et al., 2012; Balasubramanian et al., 2008; Suwaree et al., 2013; Doner and Whistler, 1973). Generally immunostimulatory substances that have been reported so far were less pure or in the form of crude extracts (Chin et al., 2013).

Fucoidan has no direct effect on virion, but it plays a role in the defense system through cellular and the humolar mechanisms to fight the virus. Mechanism of antiviral activity of fucoidan is to inhibit the absorption of viruses and the formation of virus-induced syncytium (Mandal et al., 2007). Fucoidan oral feeding may has protective effects through direct inhibition of viral replication and stimulation of the innate immune defense functions (Hayashi et al., 2008). The biologic activities of fucoidans are closely related to their molecular structures, which include fucose linkage, the sugar type, sulfate content, and molecular weight. Among these, molecular weight is one of the most important factors determining the biological activities of polysaccharides. The fucoidan with lower molecular weight showed higher resistance to cell transformation activity than high molecular weight (Jong and Hyun, 2013). Fucoidan purity and molecular weight fucoidan influence bioactivity in its function as an immunostimulant. This study was aimed at determining whether the molecular weight and purity of fucoidan are able to affect its immunostimulatory bioactivity in shrimps after the challenge test with WSSV infection.

\section{MATERIALS AND METHODS}

\section{Materials}

The raw material used in this work was obtained from a brown seaweed Sargassum binderi Sonder collected from Binuangeun-Banten at the position S $06^{\circ} 50727$ E $105^{\circ} 53.337$.
Chemical reagents used include $\mathrm{CaCl}_{2}$ (Merck), ethanol, $\mathrm{CHCl}_{2}$, methanol, $\mathrm{HCl}$, and $\mathrm{H}_{2} \mathrm{SO}_{4}$. Fucoidan standard from species Fucus vesiculosus was obtained from Sigma Aldrich. Healthy shrimp (6$8 \mathrm{~g}$ ) were obtained from Situbondo Hatchery, East Java, Indonesia.

\section{Fucoidan extraction}

The fresh brown seaweed was selected and cleaned from other undesired substances. Briefly, fresh seaweeds were macerated in $\mathrm{MeOH}: \mathrm{CHCl}_{3}: \mathrm{H}_{2} \mathrm{O}(4: 2: 1)$ for 12 hours to remove fat and pigments washed with aceton and air dried (Duarte et al, 2001). The fucoidan from defatted algal powder was extracted by soaking $0.01 \mathrm{M} \mathrm{HCl}$ of $\mathrm{pH} 4$ at the ratio of $1: 10(\mathrm{w} / \mathrm{v})$, stirred for 6 hours and siefted through a 350 mesh nylon sieve, and added with $4 \mathrm{M} \mathrm{CaCl}_{2}$, incubated for 30 minutes, and re-filtered using 500 mesh. Filtrate was diluted using distillated water until the final $\mathrm{CaCl}_{2}$ concentration of $2 \mathrm{M}$, centrifuged at $10.000 \mathrm{rpm}$ for 15 minutes, and then added with $3 \mathrm{M} \mathrm{CaCl}_{2}$ and then centrifuged at a speed of $10.000 \mathrm{rpm}$ for 15 minutes. All polysaccharides were dialyzed (cut off $10.000 \mathrm{Da}$ ) during $48 \mathrm{~h}$ (24 hours using $0.5 \mathrm{M}$ $\mathrm{NaCl}$ followed by deionized water for another 24 hours). The sample was precipitated by addition of ethanol (1:2) then left overnight. The yield was calculated from the weights of crude fucoidan divided by defatted algal dry weight. The extraction was run in triplicate, and the extraction yield was expressed as mean \pm standard deviation (SD). Each extract was combined and then analyzed.

\section{Purification of fucoidan}

Purification of fucoidan was conducted using DEAE Sephadex A-25. and eluted by gradient $\mathrm{NaCl}$ step wise elution (Duarte et al., 2001). Briefly, crude polysaccharides dissolved in $0.1 \mathrm{M}$ buffer Tris-Cl pH 7.0 were loaded to a column of DEAE Sephadex A-25 (Sigma Aldrich) fast flow $(4 \mathrm{~cm} \times 25 \mathrm{~cm})$, followed by step-wise elution using $50 \mathrm{~mL}$ of sodium chloride solutions $(0.5-2.5 \mathrm{M})$ at the flow rate of $1 \mathrm{~mL} /$ minute. Eluents $(5$ $\mathrm{mL} /$ tube) were separately collected and ethanol (HPLC grade) was added with ratio 1:2. All fractions were filtered, freeze-dried and stored at $4{ }^{\circ} \mathrm{C}$ until used.

The carbohydrate content in each eluent was determined using a phenol-sulfuric acid method (Dubois et al., 1956) using fucose (Sigma Aldrich) as the standard. Finally, all the fractions containing polysaccharides were dialyzed with deionized water and lyophilized for further study.

\section{Depolymerization of fucoidan by mild acid hydrolysis (Stanislav et al., 2012)}

Mild acid hydrolysis of crude fucoidan (CF) $1 \mathrm{~g}$ carried out using trifluoroacetic acid $\left(1 \mathrm{~N} ; 60 \mathrm{~min}\right.$; autoclave $121{ }^{\circ} \mathrm{C}, 5$ $\mathrm{mg} / \mathrm{mL}$ ). The mixtures were neutralized with $5 \% \mathrm{NH}_{4} \mathrm{OH}$ solution in water and lyophilized. LMW fraction, $\mathrm{CF}$ supernatant, yield $(62.4 \pm 0.6) \%$, was obtained by fractionation in $\mathrm{H}_{2} \mathrm{O} / \mathrm{EtOH} 1: 10$, $\mathrm{w} / \mathrm{w}$; and precipitated as high molecule weight fucoidan (HMW) yield $(37,3 \pm 0,3) \%$. 


\section{Determination of chemical composition}

Total sugar content of fucoidan was determined according to Dubois methods using phenol- $\mathrm{H}_{2} \mathrm{SO}_{4}$ reagent using Lfucose (Sigma) as the standard (Dubois et al, 1956). The sulfate content was quantified based on the $\mathrm{BaCl}_{2}$-gelatin method using $\mathrm{K}_{2} \mathrm{SO}_{4}$ (Merck) as the standard and dehydrolyzed fucoidan as the positive control. Fucoidan sample was hydrolyzed $(15 \mathrm{mg})$ in $3 \mathrm{M} \mathrm{HCl}$ for $17 \mathrm{~h}$ at $100 \mathrm{oC}$ (Dodgson and Price, 1962).

\section{Estimated molecular mass determination}

Estimated molecular mass of fucoidan was determined by Gel Permeation Chromatography (GPC) using a Perkin Elmer Series 200 equipped with refractive index detector Series 200a on a Tosoh column (TSK-Gel G 5000 PWXL stainless steel column, $7.8 \mathrm{~mm} \times 30.0 \mathrm{~cm}$ ) using water as eluent at $65^{\circ} \mathrm{C}$ with a flow rate of $0.6 \mathrm{~mL}$ min-1. All samples were filtered through $0.22-\mathrm{mm}$ filters before injection, in order to retain large aggregates (Rioux et al., 2007). Average molecular weight of fucoidan was calculated by comparison of their retention times with the calibration curve using commercially available pullulans (Shodex P-82; Showa Denko K.K., Tokyo, Japan) were used as standard molecular markers different standards $(0.62,1.0,2.17,4.88,11.3,20.0,36.6$, and $73.6 \mathrm{kDa}$ ).

\section{Nuclear magnetic resonance (NMR) and Fourier transform infrared (FTIR) spectroscopy analysis FT-IR analysis}

The qualitative analysis of the active principles of the fucoidan was done by Fourier Transmission Infra-Red (FT-IR; Shimadzu, Japan) method described by Kemp (1991). The frequency of the spectra set to analysis was between 4000 and 400 $\mathrm{cm}^{-1}$ wave number and the vibration spectrum was recorded as graphical.

\section{NMR analysis}

Fucoidan (40 mg) was dissolved in $0.7 \mathrm{ml}$ deuterium oxide $\left(\mathrm{D}_{2} \mathrm{O}\right)$, and ${ }^{1} \mathrm{H}$ and ${ }^{13} \mathrm{C}$ nuclear magnetic resonance spectra were acquired on a JEOL $400 \mathrm{MHz}$. resonance NMR spectrometer at $65{ }^{\circ} \mathrm{C}$. ${ }^{1} \mathrm{H}$ and ${ }^{13} \mathrm{C}$ NMR chemical shifts were measured in ppm relative to internal reference $\mathrm{D}_{2} \mathrm{O}$ at $4.7 \mathrm{ppm}(\mathrm{Li}$ et al., 2006).

\section{Preparation of pellet feed supplemented with fucoidan}

Four diets containing different concentrations of fucoidan were prepared by following the procedure described by Haryanti et al., 2014 (The basal diet contained $0.2 \%$ chitosan (without fucoidan) served as the control diet. The extracted fucoidan was added individually to the test diet at concentrations such as $0.3 \%$ with a corresponding decrease in the amount of cellulose. The crumble feed was dried by using hot air oven at $40{ }^{\circ} \mathrm{C}$. After drying, the finished pellet feeds were stored in plastic containers at $4{ }^{\circ} \mathrm{C}$ until use. analysis of the basal diet was $40 \%$ crude protein, and $6.5 \%$ crude lipid, dietary fiber $2.2 \%$, ash $13.0 \%$.

\section{Feeding experiment}

Healthy shrimp (6-8 g) were obtained from Situbondo Hatchery, Indonesia kept in bio-filter laboratory tanks containing artificial seawater at $26{ }^{\circ} \mathrm{C}$. After measuring the length and weight, uniform size of L. vannamei post larvae at the PL30 stage were selected from the acclimatized stock and transferred in to individual experimental tanks $(0 \%$ control and $0.3 \%$ fucoidan supplemented pellet feeds, each containing $95 \mathrm{~L}$ of filtered seawater in $100 \mathrm{~L}$ capacity FRP tanks at ambient temperature (28 ${ }^{\circ} \mathrm{C}$ ) and salinity (32 ppt). The shrimp post larvae were maintained at the stocking density of $1 / 5 \mathrm{~L}$. Mild aeration was given continuously in order to maintain the optimal oxygen level. Feeding regime was applied to all tanks throughout the experiment, and the food amount was adjusted 3 times a day (7:00, 14:30 and 20:00 h) @ 30,30, and 40\% of pellet feed, respectively. Healthy shrimp (5-8 g) were divided into five groups ( $20 \mathrm{shrimp} /$ group) and each group assayed in duplicate (2 shrimp/assay). Group1 was composed of shrimp fed with untreated fucoidan followed by saline injection (normal control (CN)). For group 2-5 delivered varian type of fucoidan with concentration $300 \mathrm{mg} / \mathrm{kg}$ weight shrimp respectively. Group 2 was composed of shrimp fed with LMW fucoidan. Group 3 was composed of shrimp fed with HMW fucoidan. Group 4 was composed of shrimp fed with extract fucoidan (CF). Group 5 was composed of shrimp fed with purified fucoidan (PF). Shrimp were fed triplicate daily with threated. The control group was fed with fucoidan un supplemented pellet feed. The unfed was collected after the respective hours of feeding and $50 \%$ water was exchanged daily during the experimental period. The feeding experiment was prolonged for 15 days. Simultaneously, duplicated were maintained in each group.

\section{WSSV challenge experiment}

After 15 days of feeding experiment, the immune response was done by a challenge test with WSSV. The WSSV infected L. vannamei shrimp (7.96.0 g $\pm 1.5 \mathrm{~g})$ were used tested shrimp. Aquarium tank with size of $60 \times 40 \times 39.5 \mathrm{~cm}$, approximately capacity of $95 \mathrm{~L}$ seawater were used in the presented trials. Each aquarium was stocked with 20 shrimps and in duplicated. Infected WSSV fresh shrimp were use as feed and fed to the shrimp once were use as feed and fed to the shrimp once time a day (10 g/ aquarium). The challenge test was done for 72 hours. The hemolymph was taken every 24 hours for observation of haemocyte and gene immunity expressions was done using RTq-PCR. The WSSV infection level was analyzed through PCR using WSSV (93 bp) primer.

The immunological parameters such as total mortality, Relative Percent Survival (RPS), total haemocyte count (THC), prophenoloxidase activity (PO), superoxide dismutase activity (SOD) and transglutaminase activity were analyzed in the haemolymph samples of shrimps before injection of WSSV (0 hours) and 24, 48, 72 hours of challenge experiment. During the challenge experiment $50 \%$ water was exchanged daily in order to remove uneaten food materials and shrimp waste materials in the experimental tanks. 


\section{Analysis of immunological parameters \\ Total haemocyte count}

Hemolymph was collected from shrimp from ventralsinus cavacity using 25-gauge needle and $1 \mathrm{~mL}$ syrenge filled with anticoagulant solution. Anticoagulant solution, modified with $\mathrm{K}$ 199 solution (Itami et al., 1994) became KC-199 with the addition of $2.38 \mathrm{~g} / \mathrm{L}$ HEPES and 5\% L-cystem. Total haemocyte cell was calculated based on cell number from hemolymph $(0.1 \mathrm{~mL})$ of challenged shrimp in anticoagulant KC-199 solution with amount of $0.4 \mathrm{~mL}$, by using a hemocytometer under light microscope with 400x magnification.

\section{Isolation of total RNA and cDNA synthesis}

Hemolymph was taken using a $25-\mathrm{G}$ needle with $1 \mathrm{~mL}$ syringe containing $0.3 \mathrm{~mL}$ of cold anticoagulant solution (2\% $\mathrm{NaCl}$; $0.1 \mathrm{M}$ glucose; $30 \mathrm{mM} \mathrm{Na}$-citrate; $26 \mathrm{mM}$ citric acid; $10 \mathrm{Mm}$ EDTA) then mixed and centrifuged at $12.000 \mathrm{rpm}, 4{ }^{\circ} \mathrm{C}$ for 15 minutes. Hemocite pellets obtained were washed with cold anticoagulant solution. Total RNA extraction was done using lysis solution with modified methods.

Synthesis of complementary DNA (cDNA) was performend using Ready-To-Go-You-Prime First Strand Beads (GE Healthcare, USA). The concentration of total RNA was as much as $3 \mathrm{mg}$ in $30 \mathrm{~mL}$ DEPC, homogenized using a low speed vortex. Total RNA in microtube were incubated at $65{ }^{\circ} \mathrm{C}$ for 10 minutes and subsequently transferred into new microtube and incubated on ice for 2 minutes. RNA solution was transferred into the first strand reaction mix beads tube. Primer race vect dT3 oligo was used to synthesize cDNA (concentration of 100 pico mole) and added as much as of $3 \mathrm{~mL}$ into reaction and left to stand for 1 minute. Microtube was incubated at $37{ }^{\circ} \mathrm{C}$ for 1 hour. cDNA solution was then added of $50 \mu \mathrm{L} \mathrm{ddH}_{2} \mathrm{O}$ and stored at $-20{ }^{\circ} \mathrm{C}$ for further analysis.

\section{Real-time quantity polymerase chain reaction (RT-qPCR) analysis of the immune gene of $L$. vannamei}

The analysis of transcriptional expression profiles of immune-related gene after challenge with WSSV were used RTqPCR with specific primers following Wang et al., (2010) consisted of (prophenoloxidase, superoxide dismutase, and transglutaminase). RT-qPCR was performed using the ABI PRISM 7500 detection system sequences with 5x Hot firepol Evagreen $\mathrm{qPCR}$ mix (ROX). cDNA amplication reaction volume was $20 \mu \mathrm{L}$ as the final concentration of $1 \mathrm{x}$ hot master mix (ROX); primary F/R, 10 picomole of each $250 \mathrm{mM}$; $\mathrm{ddH}_{2} \mathrm{O}$ was added up to volume of $20 \mu \mathrm{L}$ and cDNA $(0.01 \mathrm{ng} / \mathrm{uL})$. Conditions of thermal cycling for RT-qPCR were consisted of initial denaturation temperature of $95{ }^{\circ} \mathrm{C}$ ( 15 minutes, 15 seconds ) followed by annealing temperature of $60{ }^{\circ} \mathrm{C}$ (30 seconds) and a final extension at $72{ }^{\circ} \mathrm{C}$ for two minutes by 40 cycles. Calculation of " $\mathrm{Ct}$ " from PCR cycle threshold $(\mathrm{Ct})$ gene were tested and then normalized relative to $\mathrm{Ct} 18$ sRNA on the sample. $\Delta \mathrm{Ct}$ value calculated from (sample group tested challenged)-Ct (basic expressions, example exposure to 0 hour). Relative representation of different multiples of basic expression can be calculated by 2 $\Delta \mathrm{Ct}$

\section{RESULTS AND DISCUSSION}

Chemical analysis, molecular mass and structure of fucoidan

The crude extract yield obtained was $4.22 \pm 0.20 \%$ of the seaweed dry weight. The results of measuring carbohydrate and sulfate contents as well as molecular weight for all of four kinds fucoidan are presented in Table 1. The higher sulfate content was found in HMW fucoidan, because depolymerization of crude fucoidan with the acid causes the sulfate removal. This made the significant different of sulfate content between LMW fucoidan and HMW fucoidan, suggesting that the acid hydrolysis not only results in oligomers but also causes the release of sulfate groups.

Table 1: Results of Analysis Chemical All Kinds Fucoidan.

\begin{tabular}{llll}
\hline Kinds of Fucoidan & $\begin{array}{c}\text { Total } \\
\text { carbohydrate } \\
(\%)\end{array}$ & $\begin{array}{c}\text { Total } \\
\text { sulfate } \\
(\%)\end{array}$ & $\begin{array}{c}\text { Molecular } \\
\text { Weight } \\
\mathbf{\text { x10 }} \\
\text { Dalton }\end{array}$ \\
\hline LMW & 65.23 & 1.2 & 7.53 \\
CF & 74.25 & 8.44 & 10,68 \\
HMW & 82.54 & 7.8 & 8.28 \\
PF & 70.23 & 3.23 & 8,00 \\
Fucoidan commercial (FK) & 84.23 & 7.82 & 8.18 \\
Fucus vesiculosus & & & \\
\hline
\end{tabular}

FT-IR spectroscopy is used to identify where the sulfates are positioned in the structure of fucoidan. The main information for the position of sulfate groups is contained in the ranges of wavenumber $1500-700 \mathrm{~cm}^{-1}$. It has been reported that the broad signal at $1259 \mathrm{~cm}^{-1}$ (-S-O antisymmetric stretching vibration of the sulfate group) is representative of the total sulfate esters in polysaccharides. The signal at $823 \mathrm{~cm}^{-1}$ characterize the sulfation the equatorial position where the sulfate ester binds to the of fucose to form sulfate fucose. This result is in agreement with IR spectrum indicating that fucoidan being studied have close structural similarity to commercial fucoidan (Figure 1) (Zvyagintseva et al., 1999; Usov and Bilan., 2009). The NMR spectroscopy is used to identify the composition and the structure of fucoidan. The NMR spectroscopy is used to identify the composition and the structure of fucoidan. The NMR profiles described below are only for LMW and PF (Figure 2). The NMR profiles for HMW and $\mathrm{CF}$ are not shown here due to the overlapped peaks. Based on our ${ }^{1} \mathrm{H}$ NMR data, the presence of the chemical shift for the methyl group was observed at $1.0 \mathrm{ppm}$. Monosaccharides generally do not have alkyl group, and therefore their chemical shifts were in the range of 3-4 ppm instead of 1 ppm. The chemical shift of $1 \mathrm{ppm}$ is not common in carbohydrate. This chemical shift showed the specificity of fucose which has the methyl group $\left(\mathrm{CH}_{3}\right)$ at $\mathrm{C}-6$ position. The chemical shift at $96 \mathrm{ppm}$ ${ }^{13} \mathrm{C}$ NMR is charaterisctic of carbons of $\mathrm{C}-1$ of carbohydrate. The peak appears at the most downfield shift (5 ppm) indicating a proton bound to the carbon containing a sulfate group. This is supported by the appearance of the peak at $75 \mathrm{ppm}{ }^{13} \mathrm{C}$ NMR spectrum (Figure 2b). 


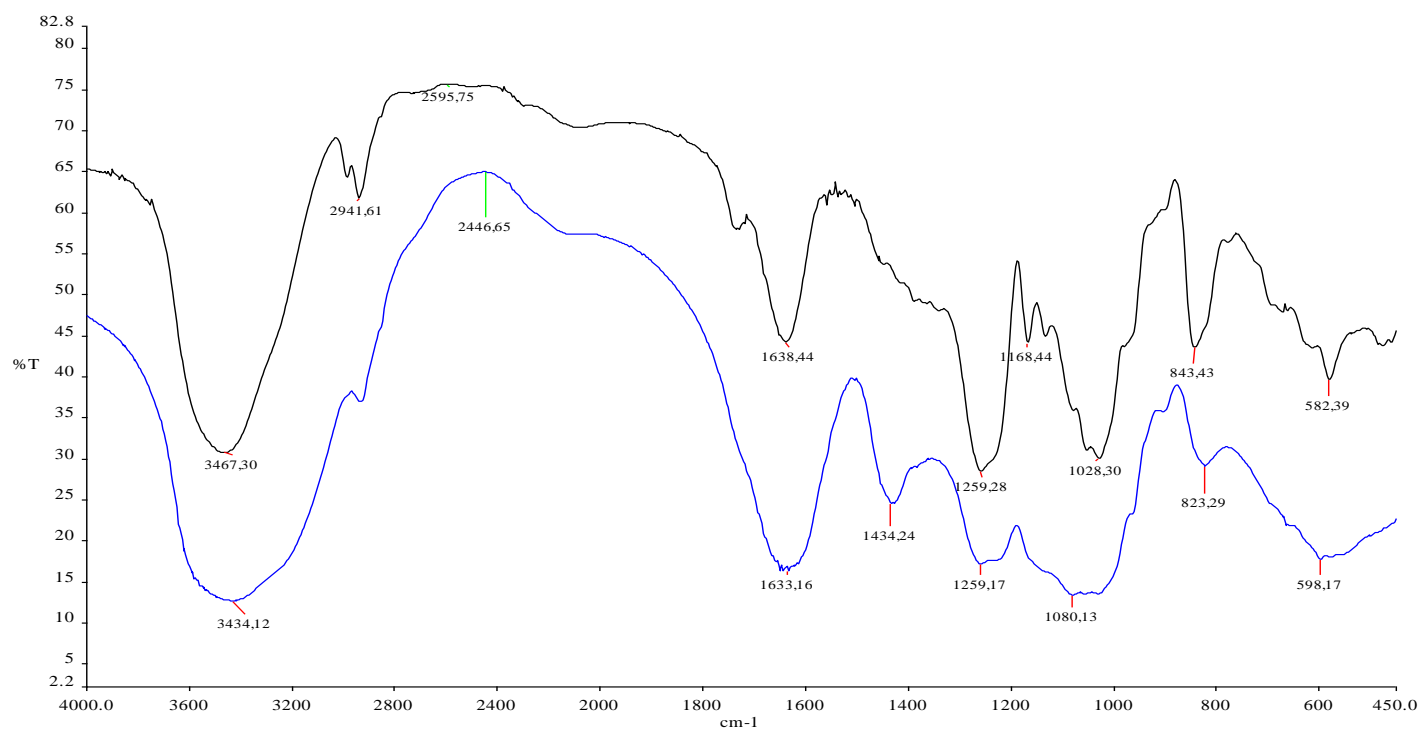

Fig. 1: FT-IR spectra of crude fucoidan Sargassum binderi Sonder and a commercial fucoidan from Fucus vesiculosus.

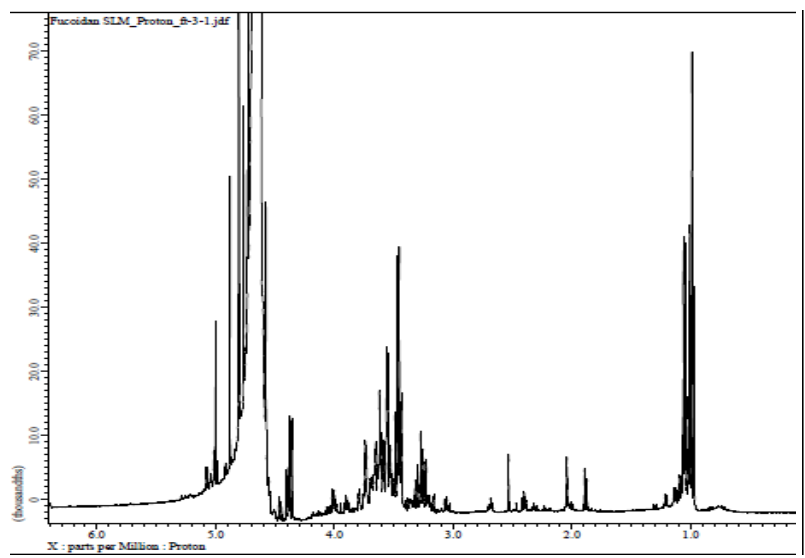

Fig. 2a. ${ }^{1} \mathrm{H}$ NMR

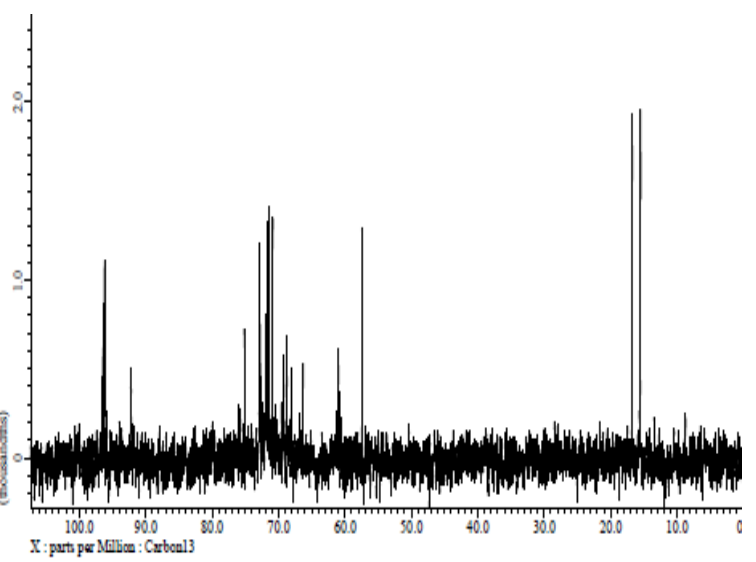

2b. ${ }^{13} \mathrm{C}$ NMR

Fig. 2: NMR Spectra of fucoidan extracted from brown seaweed Sargassum binderi Sonder.

\section{Immunostimulant and resistance against WSSV infection of fucoidan}

Nutrition composition of the given food for assay ( in the form of crumble, PV feed code 1 type) contains protein (40\%), fat $(6.5 \%)$, hoarse $(2.2 \%)$, ash $(13.0 \%)$, and water content $(11.0 \%)$. The statistical calculation revealed that HMW fucoidan enhanced the growth of the shrimp L. vannamei significantly, as indicated with the increased body length $(8.35 \pm 0.59) \mathrm{cm}$ and weight $(10 \pm$ $0.29) \mathrm{g}$ if compared with the controls (without fucoidan) that have growth length of $7.45 \pm 1.27$ and weight of $9.95 \pm 0.60$. Similar result was reported by Traifalgar et al., (2009) on PL 15 shrimps P. monodon for 30 days increased the weight $(13.5 \pm 0.59 \mathrm{mg})$ with the specific growth rate (SGR) of 8-7.9\%/day. Our feeding observation was done on shrimps cultivated in the tank containing sea water with salinity of $32 \mathrm{ppt}, \mathrm{pH}$ of 8 , temperature of $28 \pm 1{ }^{\circ} \mathrm{C}$ and the oxygen levels of 6-7 ppm.

The lowest mortality of the infected shrimps were observed for treatment with HMW fucoidan about $10 \%$, followed with LMW fucoidan (40\%), CF (45\%), PF (55\%), and $\mathrm{CN}$
(55\%). We assumed that the low mortality for HMW fucoidan was related to sulfate content of HMW fucoidan. Sulfate content HMW fucoidan $(7.8 \%)$ is higher than LMW fucoidan $(1.2 \%)$. The sulfate content may contribute to the effect of stimulant to shrimp. However the effect stimulant is not only cause by sulfate content, but also is influenced by molecule size. To digestion higher moleculer weight require longer time.

After 24 hours of infection, the shrimp individuals fed with CF showed a $10 \%$ mortality (Fig. 4). The shrimps fed without fucoidan supplement (negative control) showed $80 \%$ mortality at 48 hours and at 72 hours $90 \%$ mortality after infection. After 72 hours of infection, $80 \%$ mortality was observed for the shrimps fed with HMW fucoidan; whereas $70 \%$ mortality was found for those treated with CF and LMW fucoidan. The survival rate of the shrimps fed with all four kinds of fucoidan was in the range of 20-30\%, which was twice than the negative control (20\% survival rate). Similar result was also observed after 72 hours of infection, in which the survival rate of the fucoidanfed shrimps was twice than the negative control. 


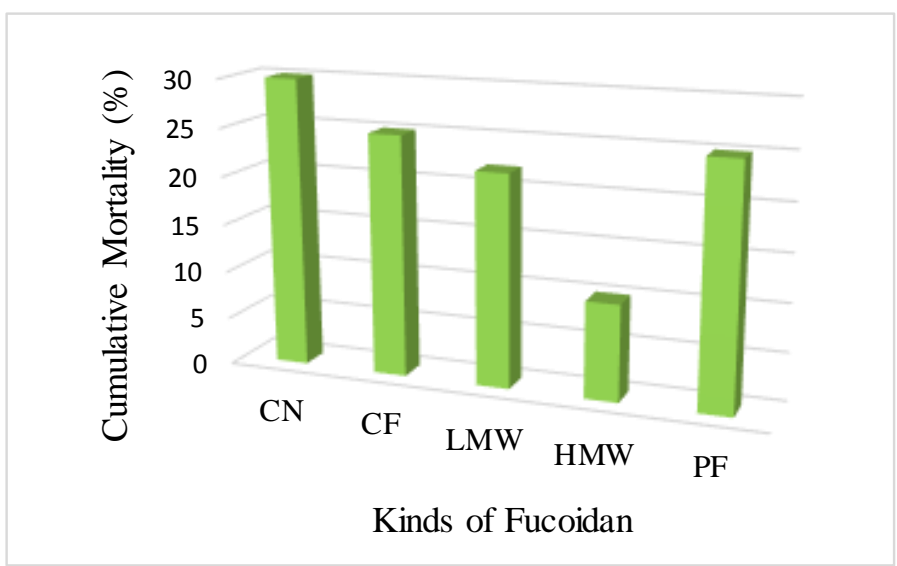

Fig. 3: Mortality Shrimp during Experiments

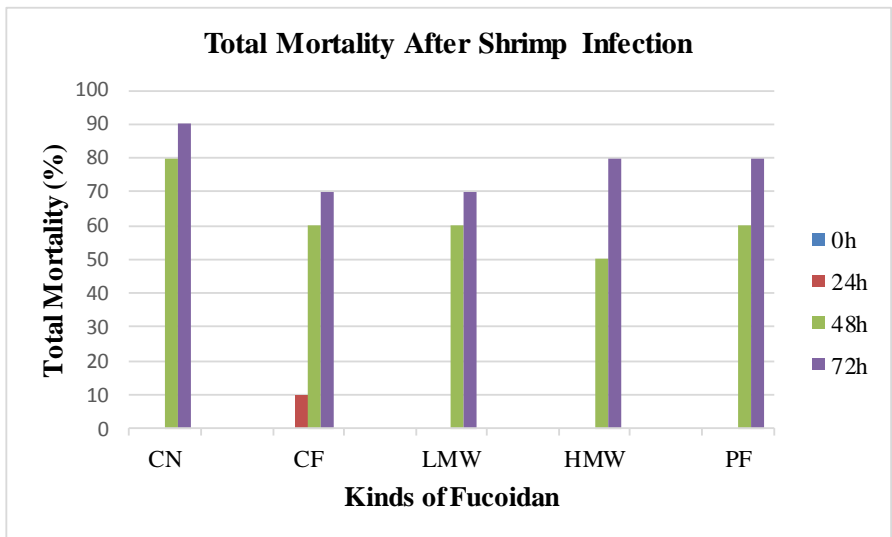

Fig. 4: Mortality Shrimp After Challenge Test with WSSV

The highest total haemocyte number $\left(1,9 \times 10^{5}\right.$ cell $\left./ \mathrm{mL}\right)$ was observed on the non-infected shrimps fed with HMW fucoidan. The lowest haemocyte number $\left(1.4 \times 10^{5} \mathrm{cell} / \mathrm{mL}\right)$ was found in the non-infected inividuals, administered with CF. This suggests that HMW fucoidan resulted from the depolymerization of CF was more easily absorbed by the shrimps compared with CF. Similar study was reported by Traifalgar et al., (2013) showing that feeding with immunostimulant (Vibrio harveyi lipopolysaccharide (VLP) and $\beta$-glucan) increased the total haemocyte number.

The infection of the virus stimulates the activation of the cascade proPO system, in which PPAE (prophenoloxidase activating enzyme) as a terminal-specific protease converted prophenoloxidase (proPO) into the active form phenoloxidase (PO) through proteolytic activity. Futhermore, activated PO oxidizes phenol to form quinone. Futher polymerization of quinone leads to formation of melanin that is responsible of killing pathogen and healing wound caused by encapsulation and regeneration of ROS (Cerenius et al., 2010); Nappi and Christensen, 2005; Pakkakul et al., 2015).

The highest total haemocyte number $\left(2.2 \times 10^{5}\right.$ cells $\left./ \mathrm{mL}\right)$ was found for the infected individuals fed with HMW fucoidan at hour 0 . Whereas the lowest number $\left(0.6 \times 10^{5}\right.$ cells $\left./ \mathrm{mL}\right)$ was observed on those administered with LMW fucoidan. In general after 24 hours of infection, the total haemocyte number decreased significantly. The 24-hour infected shrimps physically looked less moving, appetite and stressful. This is confirmed by a large number of the remaining food residues in the experimental tub. In the challenge test for 48 hours of infection, total haemocyte number for the CF-fed individuals decreased $82.3 \%$. Similar result was observed for the PF-fed individuals, in which the total haemocyte number showed the decrease of $35.3 \%$. In contrast, the individuals fed with LMW fucoidan exhibited significant increase of total haemocyte number $40.0 \%$. Total haemocyte number of the HMW fucoidan-fed shrimps begun to increase slightly if compared with the 24-hour observation.

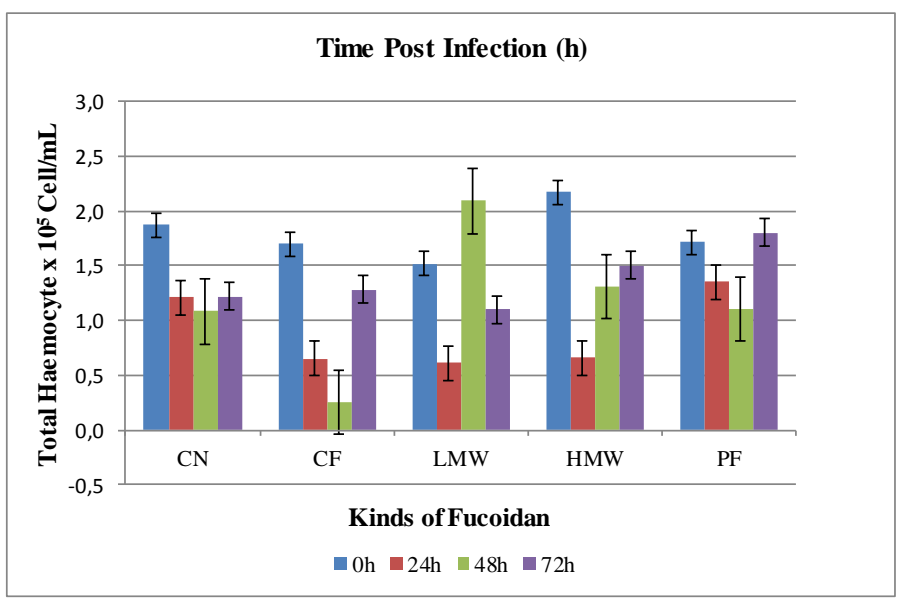

Fig. 3: Total Hemocyte Count after Challeng Test with WSSV

In the challenge test for 72 hours of infection, the LMW fucoidan-fed individuals exhibited the decrease in total haemocyte number $26.6 \%$. Interestingly the total haemocyte number of the PF-fed individuals increased slightly by $5.8 \%$ compared with the hour 0. Another treatment with HMW fucoidan showed slight increase by $15 . \%$. Surprisingly significant increase by $333.3 \%$ in total haemocyte number was found in the individuals fed with $\mathrm{CF}$ in comparation with the 48-hour observation.

Based on the results described above, it is likely the treatment of the infected shrimp with LMW fucoidan stimulates the fast increase of total haemocyte number in short period of time (24 hours). We assumed that LMW fucoidan is more easily transported across the cell membrane; and therefore it immediately interacts with the haemocyte receptors. This was also reported by Tawut $e t$ al., (2015) that polysaccharide with lower molecular weight provides greater opportunities for material immunodulator in the haemocyte pathway. Three other treatments showed the slow increase after 48 hours of infection. Shortly after feeding with fucoidans, the total haemocyte number did not increase immediately, because it required time to metabolize them. In particular, HMW fucoidan consumed by the infected shrimps may undergo hydrolysis into smaller MW units that are subsequently transported into the cell via cell membrane. Inside the cell, the immun system is stimulated by interaction between the fucoidan sulfate groups and the haemocyte receptor, as has recently been by 
Tawut et al., (2015) for HMW sulfated galactan from Gracilaria fisheri $(100 \mathrm{kDa})$.

\section{Expression of gene-related immunity}

After feeding for 15 days, WSSV challenge tests were conducted at the level of gene expression for prophenoloxidase (proPO), superoxide dismutase (SOD) and transglutaminase (Tgase) using RT-qPCR. The test results were presented in Figures $6 \mathrm{~A}, 6 \mathrm{~B}$ and $6 \mathrm{C}$.

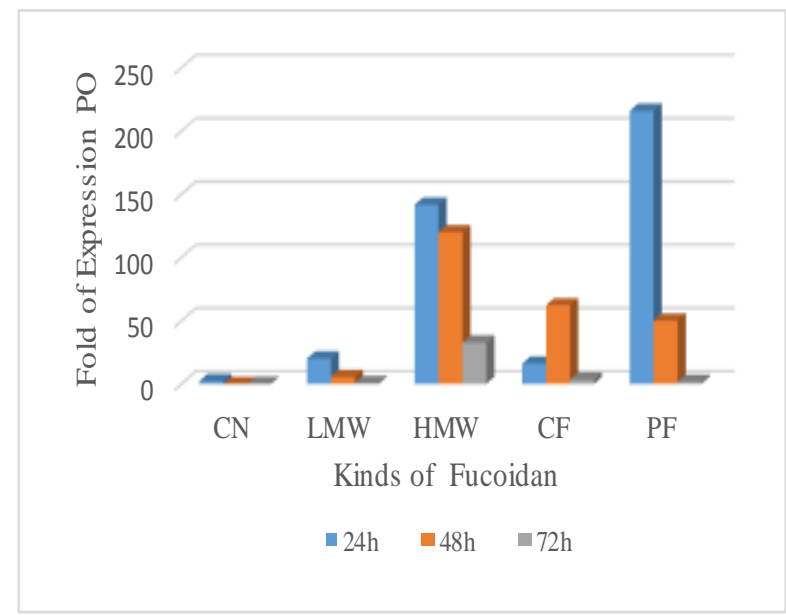

Fig. 6A. Fold of Expression PO

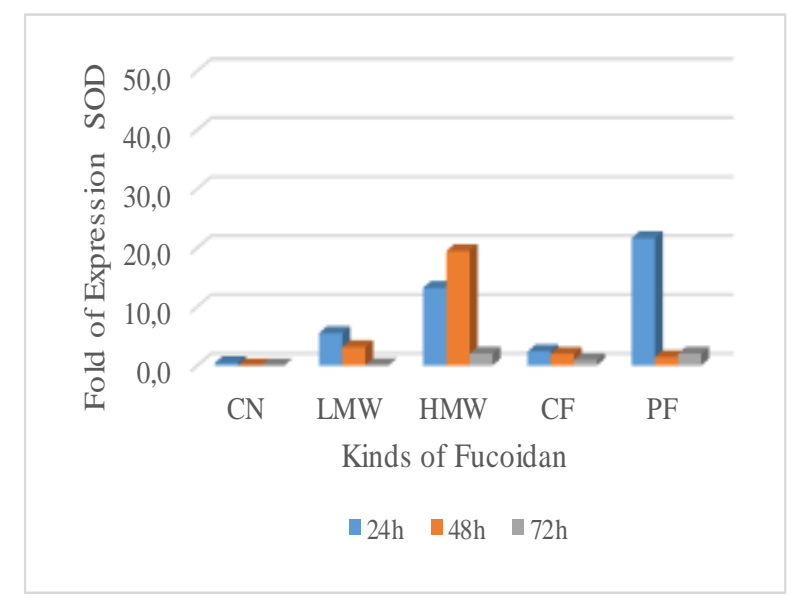

Fig. 6B. Fold of Expression SOD

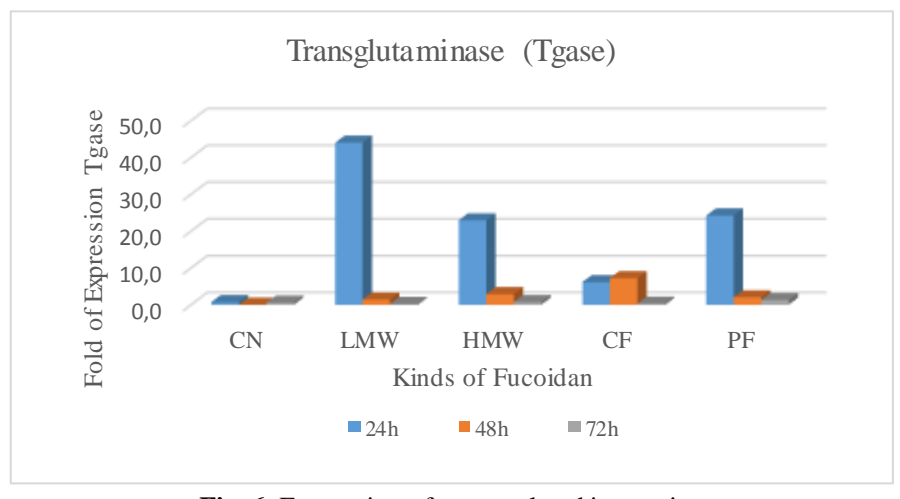

Fig. 6. Expression of gene-related immunity

Prophenoloxidase (proPO)
Detection using RT-qPCR is intended to know the transcription level of proPO gene during WSSV infection. Expression levels of proPO gene were individually normalized using 18s RNA as the endogenous reference to indicate the normal condition (without infection) of the challenge test at hour 0. ProPO gene activation system was significantly improved upon feeding with fucoidans. The highest trancriptional level of proPO was observed on PF treatment, which was 100 times compared with the control at the hours 24. Similar result was observed for other fucoidan treatment. However at hour-48, gene expression of proPO decrease, except for CF. The highest level of proPO gene transcription was found in the individuals fed with $\mathrm{PF}$, followed with HMW fucoidan, LMW fucoidan and CF. The highest transcriptional level of proPO was observed at the 24-hour infection. However, at the 48-hour infection, the trancriptional level of proPO gene decreased. In general, feeding with fucoidan improved proPO gene transcriptional level in the range 8-100 times compared to control.

In shrimps, proPO is localized in the haemocytes, but it plays a major role in the humoral response that is triggered by immunostimulatory activity of fucoidan. The proPO cascade in shrimps commonly occur through recognition of the cell wall components of bacteria or fungi by pattern recognition proteins (Fagutao et al., 2011). In this present study, we used fucoidan to stimulate the proPO cascade through proteolitic activity. This proPO cascade process is initiated by serine protease cascade activation that converts the proPO-activating enzyme (PPAE) to an active proteinase. Then proteinase catalizes the conversion of the inactive enzyme precursor, proPO, into phenoloxidase (PO). PO, a copper containing oxidase, eventually catalyzes the oxidation of tyrosine to produce toxic quinone substances and other short-lived reaction intermediates that lead to the formation of melanin. It has been shown that melanin binds to the surface of bacteria and increase the adhesion of haemocytes to bacteria, thus accelerating their removal by nodule formation (Cerenius et al., 2008). Melanization, which is a major innate defense system in invertebrates, is controlled by the enzyme phenoloxidase. However, PO activity does exist in the plasma of haemolymph without pathogenic infections (Masuda et al., 2012). The type proPO in which Vannamei shrimps was conducted proPO1 refer to NCBI data base (AF 521948) (Amparyup et al., 2009). The expression level of proPO increases as a response towards WSSV infection, leading to the increased defense system (Wang et al., 2010).

\section{Superoxide dismutase (SOD)}

Superoxide dismutase (SOD) is an antioxidant enzyme mediating oxidative damage. On the crustacean haemocyte, the antimicrobial activity is a derivative of reactive oxygen species (ROS) during and after phagocytosis. This ROS production could lead to tissue damage on the shrimp. ROS could be a source of disease due to the oxidative stress. To prevent the formation of ROS, it requires an anti-oxidative substance. SOD serves as the first eliminator of ROS and converts it into hydrogen peroxide and 
oxygen. In the case that ROS is formed excessively, it can cause damage to the host cells. Under this condition, SOD acts to control excessive ROS (Fuhua and Jianhai, 2013). In this study, the level of SOD gene expression after WSSV challenge test increased during 24-48 hours of infection, as shown in the Figure 6B.

In this study, the manganase superoxide dismutase (MnSOD) type plays an important role in crustacean immune defense reaction by eliminating oxidative stress (Zhang et al., 2007; Zhao et al., 2014). At the infection of $48 \mathrm{~h}$, the SOD transcriptional level of shrimps treated with all four kinds of fucoidan (in particular HMW and PF) were higher than the control, suggesting that during the phagocytosis on WSSV, the level of ROS increases and more SODs are needed to reduce the effects of ROS. The highest increase in SOD was found at the individuals fed with PF, followed with HMW fucoidan, LMW fucoidan and $\mathrm{CF}$ in the range 2-21 times compared to the control.

\section{Transglutaminase (Tgase)}

Transglutaminase clotting system plays a role in shrimp. Level of Tgase gene expression for all fucoidans treatment was significantly higher compared to the control. The treatment of fucoidans enhance the Tgase level. The highest level of Tgase was observed in the individuals fed with LMW fucoidan, then PF, HMW fucoidan and CF in the range 2-44 times compared to the control at the 24-hour infection. In the injured shrimp, Tgase acts quickly to prevent the loss of the hemolymph. Tgase with its cofactor $\mathrm{Ca}^{2+}$ plays a role in the coagulation system, which triggered polymerization with hemolymph protein clotting. Protein clotting acts to prevent the spread of pathogens through hemocoel. The requirement of the natural form of $\varepsilon^{-}(\gamma-$ glutamyl $)$ Tgase catalyses cross binding between glutamine and lysine, and therefore it inhibits the blood coagulation in the gills, liver, intestinal, hepatopancreatic, haemocyte, and lymphoid (Sritunyalucksana and Kenneth, 2000).

In general, the enhancement of the shrimp immune system was indicated by proPO; SOD or Tgase during 24 to 48 hours of infection. After that, the gene expression levels associated with its immunity decreased downhill. This is a constraint on the effectiveness of immunostimulant, in which time its effectiveness tends to be short. Several of the research that has been done by Sung et al., (2001), they observed that turned out to be the effect of glucan on soaking $P$. monodon Vibrio bacteria or that benefit lasts for a maximum of 24 hours before finally descending to the level of control. Effect of carrageenan by way of soaking as much as 200, 400, $600 \mathrm{mg} / \mathrm{L}$ in Litopenaeus vannamei, after 3 hours of tested challenge virus WSSV improved immunity (PO activity, activity of the serine protease) and then decreased after 5 hours (Yu et al., 2014).

Sargassum hemiphyllum var.chinensis administration increases the number of haemocytes, phenoloxidase (PO) activity, respiratory burst and lysozyme activity after 3 hours, after 5 hours return to forming of basal (Truong et al., 2011). This is the difference immunostimulant vaccine, which vaccine immune system at the same antigens tends resistant for a prolonged time
(Valerie et al., 2003). One way to increase the effectiveness immunostimulant time is by giving in a prolonged time and the amount added. Feeding Sargassum wightii on P. monodon over 90 days can increase the maximum survival of $96.66 \%$ (Huxley and Lipton, 2009). The crude fucoidan of Sargassum horneri on juvenile crayfish with a concentration of $0.05 \%, 0.1 \%$ and $0.2 \%$ per $\mathrm{kg}$ body weight for 7 weeks can increase SOD after the challenge test Aeromonas hydrophila (Qing et al., 2014).

Recently, a set of immune pattern recognition receptors (PRRs) that play important roles in innate resistance have been identified in penaeid shrimp including lipopolysaccharide and $\beta-1$, 3-glucan binding protein (LGBP), and toll receptors. Recognition of pathogens by PRRs triggers activation of a serine protease cascade which subsequently cleaves prophenoloxidase (proPO) to generate phenoloxidase ( $\mathrm{Yu}$ et al., 2016). It has been shown that the amino acid sequence of LGBP deduced from LGBP cDNA of Penaeus chinensis contains a potential recognition motif for $\beta-1,3$ linkage of polysaccharides (Chizhov et al., 1999). Sulfate galactan's structure of $G$. fisheri contains the $\beta$-1, 3-linkage which may interact with LGBP localized on the membrane of haemocytes with subsequent generation of active phenoloxidase enzyme. Another receptor activity that plays a key role in the innate immune system involves the Toll-like receptors (TLRs).

The results of the present study suggested that the brown seaweed Sargassum wight ii was major source of fucose and sulfate containing biologically active polysaccharide-fucoidan, it may be considered as good immunostimulant in shrimp diseases additionally or instead of commercial antibiotics. The revealed structures of (1-6)- $\beta$-D-galactose, $\alpha$-L-fucose and $\beta$-D mannuronic acid and it was suggested that the sulfates of the fucoidan act against WSSV infection while fucose, galactan and mannuronic acid stimulate the immune system of shrimp (Grassian et al., 2012; Tawut et al., 2015). The efficiency of antiviral agent activity of SPs depends on the density and position of the sulfate groups on sugar residues, and it was reported that SPs from seaweed contain as many as 35-60 sulfate groups per one hundred sugar residues demonstrated a strong antiviral agent activity (Marais et al., 2001) These protective antioxidants are increased at the level of transcription (Kanokpan et al., 2014) for the rapid elimination of extreme stress-related reactive oxygen species (ROS) induced by pathogens. It is possible. Therefore, to speculate that sulfate galactans bound to TLRs in L. vannamei, which up-regulates the antioxidant enzyme systems and eliminates extreme ROS thus preserving immune homeostasis. At the same time, considering the viruses host interaction, it could be postulated that SG binding with TLR interrupts the viral usage of the TLR-NF-kB pathway for viral replication in the host cell (Witvrouw et al., 1997).

\section{CONCLUSION}

Immunostimulatory activity levels of fucoidan toward shrimps infected with WSSV virus are affected by the molecular weight, sulfate content, and purity of fucoidan. Among the three immunity-related genes tested, the transcriptional level of PO gene 
have the most significant effect of improving the shrimp's defense system.

\section{ACKNOWLEDGMENT}

We thank Prof. Dr Haryanti for her technical support during the experiment.

Financial support and sponsorship: This research was financially supported by APBN (National Budget 2015) granted to Ministry of Marine Affairs \& Fisheries Republic of Indonesia.

Conflict of Interests: There are no conflicts of interest.

\section{REFERENCES}

Amparyup P, Charoensapsri W, Tassanakajon A. Two prophenoloxidases are important for the survival of Vibrio harveyi challenged shrimp Penaeus monodon. Developmental and Comparative Immunology, 2009; 33: 247-56.

Bachere E, Delphine D, Philippe B. Penaeidins antimicrobial peptides of shrimp: a comparison with other effectors of innate immunity. Aquaculture, 2000; 191: 71-88.

Balasubramanian G, Sarathi M, Venkatesan C, John TD, Sahul Hameed AS. Oral administration of antiviral plant extract of Cynodon dactylon on a large scale production against white spot syndrome virus (WSSV) in Penaeus monodon. Aquaculture, 2008; 279: 2-5.

Bilan MI, Alexey AG, Alexander SS, Nikolay E, Nifantiev, Anatolii I. Usov. Structure of a fucoidan from the brown seaweed Fucus serratus. Carbohydrate Research, 2006; 341: 238-45.

Cerenius L, Kawabata S, Lee BL, Nonaka M, Söderhäll K. Proteolytic cascades and their involvement in invertebrate immunity. Trends Biochem. Sci, 2010; 35: 575-83.

Cerenius L, Lee BL, Söderhäll K. The proPO-system: Pros and cons for its role in invertebrate immunity. Trends Immunol, 2008; 29: $263-71$

Chen YY, Chen JC, Lin YC, Yeh ST, Chao KP, Lee CS. White Shrimp Litopenaeus vannamei that have received Petalonia binghamiae Extract Activate Immunity, Increase Immune Response and Resistance against Vibrio alginolyticus. J Aquac Res Development, 2014: 5-6; http://dx.doi.org/10.4172/2155-9546.1000268.

Chin-Chyuan C, Liang-Hua G, Winton C. Effect of Dietary Administration of Hot-water Extracts of Sargassum cristaefolium on the Immunity of White Shrimp Litopenaeus vannamei and Its Resistance Against Vibrio alginolyticus. J. Fish. Soc. Taiwan, 2013; 40(1): 27-41.

Chizhov AO, Dell A, Morris HR, Haslam SM, McDowell RA, Shashkov AS. A study of fucoidan from the brown seaweed Chorda filum. Carbohydr Res, 2001; 320(1):108-19.

Chotigeat W, Suprap T, Kidchakan S, Amornrat P. Effect of Fucoidan on Disease Resistance of Black Tiger Shrimp. Aquaculture, 2004; 233: 23-30.

Dodgson, KS. and Price RG. A note on the determination of the ester sulphate content of sulphated polysaccharides. Biochemistry, 1962; 84: $106-10$

Dubois M, Gilles KA, Hamilton JK, Rebers PA, Smith F. Colorimeter method for determination of sugars and related substances. Analytical Chemistry, 1956; 28: 350-6.

Dechamag P, Intaraphad U, Phpngdara A, Chotegeat W. Expression of a phagocytosis activating protein (PAP) gene in immunized black tiger shrimp. Aquaculture, 2006; 255: 165-72.

Doner LW and Whistler RL. Fucoidan Industrial Gums Polysaccharide and their Derivatives. Academic Press, New York, 1973, pp. 115-20.
Duarte M, Cardoso M, Noseda M. Structural studies on fucoidans from the brown seaweed Sargassum stenophyllum. Carbohydrate Research, 2001; 333: 281-93.

Fagutao FF, Kondo H, Aoki T, Hirono I. Prophenoloxidase has a role in innate immunity in penaeid shrimp. Diseases in Asian Aquaculture VII. Fish Health Section, Asian Fisheries Society, Selangor, Malaysia. 2011: 171-76

Flegel TW. Special topic review: major viral diseases of the black tiger prawn (Penaeus monodon) in Thailand. World J Microb Biot, 1997; 3(4): 433-42.

Fuhua Li and Jianhai Xiang. Recent advances in researches on the innate immunity of shrimp in China. Develpmental and Comparative Immunology, 2013; 39: 11-26.

Fridovich Irwin. Superoxide Radical Superoxide Dismutase., Superoxide Radical and Superoxide Dismutase Annual Review of Biochemistry, 1995; Vol. 64: 97-112 (Volume publication date July 1995) DOI: 10.1146/annurev.bi.64.070195.000525.

Haryanti, Ahmad M, Sari BMS, Fahrudin, I Gusti NP, Ida KW. The Effect of Probiotic on Immunity Improvement in The fry and Spawner Production of Pacific White Shrimp Litopenaeus vannamei., Indonesian Aquaculture Journal, 2014; Vol 9 No.2: 137-52.

Hayashi K, Nakano T, Hashimoto M, Kanekiyo K, Hayashi T. Defensive effects of a fucoidan from brown alga Undaria pinnatifida against herpes simplex virus infection. Int. Immunopharmacol, 2008; 8:109-116. doi: 10.1016/j.intimp.2007.10.017

Holmblad, Soderhall, Halmblad T, Soderhall K. Cell adhesion molecules and antioxidative enzymes in a crustacean, possible role in immunity. Aquaculture. 1999; 172: 111-23.

Huxley AAJ and Lipton AP. Immunomodulatory effect of Sargassum wightii on Penaeus monodon (Fab.). The Asian Journal of Animal Science, 2009; Vol. 4 Issue 2: 192-6.

Grassian I, Madasamy S, Thangapandi M, Srinivasan R, Arunachalam P. The effect of fucoidan from brown seaweed Sargassum wightii on WSSV resistance and immune activity in shrimp Penaeus monodon (Fab). Fish \& Shellfish Immunology, 2012; 32: 551-64.

Itami $\mathrm{T}$, Takashi $\mathrm{Y}$, Tsuchihira $\mathrm{E}$, Igusa $\mathrm{H}$, Kondo $\mathrm{M}$. Enhancement of disease resistance of kuruma prawn Penaeus japonicus and increas in phagocytic activity of prawn haemocyte after Oral Administration of $\beta-1,3$-glucan (schizophyllan) in Chou et al, (Eds). Proceeding of third Asian Fisheries Forum. The Asian Fisheries Society, Manila Philippines, 1994, p. 375-8.

Johansson and Soderhall. Cellular Immunity in Crustaceans and the proPO System. Reviews Parasitology Today, 1989; Vol 5 (6): 171-6.

Jong-il Choi and Hyun-Joo Kim. Preparation of low molecular weight fucoidan by gamma-irradiation and its anticancer activity. Carbohydrate Polymers, 2013: 358- 62.

Kemp W. "Organic spectroscopy". 3rd ed. Macmillan Education, 1991: 393

Kanokpan W, Tawut R, Jantana P. Immunostimulatory activity of sulfated galactans isolated from the red seaweed Gracilaria fisheri and development of resistance against white spot syndrome virus (WSSV) in shrimp. Fish \& Shellfish Immunology, 2014; 36: 52-60.

Li B, Xin JW, Sun JL, Xu SY. Structural investigation of a fucoidan containing a fucose-free core from the brown seaweed Hizikia fusiforme. Carbohydrate Res, 2006; 341: 1135-46.

Masuda T, Otomo R, Kuyama H, Momoji K, Tonomoto M, Sakai S. A novel type of prophenoloxidase from the kuruma prawn Marsupenaeus Japonicus contributes to the melanization of plasma in crustaceans. Fish \& Shell fish Immunology, 2012; 32: 61-8

Munoz M, Cedeno R, Rodriguez J, Van der Knaap WPW, Mialhe E, Bachere E. Measurement of reactive oxygen intermediate production in haemocytes of the penaeid shrimp Penaeus vannamei. Aquaculture, 2000; 191: 89-107.

Mandal P, Mateu CG, Chattopadhyay K, Pujol CA, Damonte EB, Ray B. Structural features and antiviral activity of sulphated fucans from the brown seaweed Cystoseira indica. Antivir Chem Chemother, 2007; 18:153-62. 
Marais MF, Joseleau JP. A fucoidan fraction from Ascophyllum nodosum. Carbohydrate Res, 2001; 336(2): 155-9.

Nappi A J, Frey F, Carton Y. Drosophila serpin 27A is a likely target for immune suppression of the blood cell-mediated melanotic encapsulation response. Journal of Insect Physiology, 2005; 51(2): $197-$ 205.

Pholdaeng K and Sunanta P. Studies on the immunomodulatory effect of polysaccharide gel extracted from Durio zibethinus in Penaeus monodon shrimp against Vibrio harveyi and WSSV. Fish \& Shellfish Immunology, 2010; Volume 28, Issue 4: 555-61.

Pakkakul S, Walaiporn C, Sudarat C, Saengchan S, Anchalee T, Piti A. A shrimp pacifastin light chain-like inhibitor: Molecular identification and role in the kontrol of the prophenoloxidase sistem. Developmental and Comparative Immunology, 2016; 54: 32-45.

Qing Y, Rui Y, Ming L, Qicun Z, Xiongpei L, Zacharia CE. Effects of dietary fucoidan on the blood constituents, anti-oxidation and innate immunity of juvenile yellow catfish (Pelteobagrus fulvidraco). Fish \& Shellfish Immunology, 2014; 41: 264-270.

Rioux LE, Turgeon SL, Beaulieu M. Characterization of polysaccharides extracted from brown seaweeds. Carbohydr Polym, 2007; 69 (3): $530-37$

Sarathi M, Martin C, Simon, VP, Ishaq AS, Rajesh KAS, Sahul H. Silencing VP28 Gene of White Spot Syndrome Virus of Shrimp by Bacterially Expressed dsRNA. Marine Biotechnology, 2007; Vol 10: 198206. DOI: $10.1007 / \mathrm{s} 10126-007-9052 y$

Sirirustanaun N, Chen JC, Lin YC, Yeh ST, Liou CH, Chen LL. Dietary administration of a Gracilaria tenuistipitata extract enhances the immune response and resistance against Vibrio alginolyticus and white spot syndrome virus in the white shrimp Litopenaeus vannamei. Fish and Shellfish Immunology, 2011; 31: 848-55.

Smith V.J. and Soderhall K. $\beta-1,3$ glucan activation of crustacean hemocyte in Vitro and in vivo Biol. Bull, 1983; 164: 299-314.

Söderhäll K and Cerenius L. Crustacean immunity. Annual Review of Fish Disease, 1992; 2: 3-23.

Sritunyalucksana Kallaya and Kenneth Soderhall. The proPO and clotting system in crustaceans. Aquaculture, 2000; 191: 53-69.

Stanislav DA, Natalia M. Shevchenko, Svetlana P. Ermakova, Olesya S, Vishchuk, Evgeny L. Nazarenko, Pavel SD, Tatyana N, Zvyagintseva. Anticancer activity in vitro of a fucoidan from the brown alga Fucus evanescens and its low-molecular fragments, structurally characterized by tandem mass-spectrometry. Carbohydrate Polymers, , 2012; 87: 186- 94.

Suwaree K, Jiann-Chu C, Dedi FP, Yong-Chin L, Su-Tuen Y, Chyng-Hwa L. Fucoidan effectively provokes the innate immunity of white shrimp Litopenaeus vannamei and its resistance against experimental Vibrio alginolyticus infection. Fish \& Shellfish Immunology, 2013; 34: 280-90.

Sung HH, Hsu SF, Chen CK, Ting YY, Chao WL. 2001. Relationships between disease outbreak in cultured tiger shrimp (Penaeus monodon ) and the composition of Vibrio communities in pond water and shrimp hepatopancreas during cultivation. Aquaculture, 2001; 192: 101

Takahashi Y, Uehara K, Watanabe R, Okumura T, Yamashita $\mathrm{T}$, Omura H. Efficacy of oral administration of fucoidan, a sulfated polysaccharide in controlling white spot syndrome in kuruma shrimp in Japan. In: Flegel TW, editor. Advance in shrimp biotechnology. Bangkok: National Center for Genetic Engineering and Biotechnology, 1998: 171-3.

Traifalgar PF, Serrano AE, Corre V, Kira HK, Tung HT, Michael FL, Kadel A, Laining A, Yakoyama, Ishikawa, Koishowo. Evaluation of Dietary Fucoidan Supplementation Effects on Growth Performance and Vibriosis Resistance of Panaeus monodon Postlarvae. Aquaculture Science, 2009; 57 (2): 167-74.
Traifalgar RFM, Corre VL, Serrano AE. Efficacy of dietary immunostimulants to enhance the immunological responses and Vibriosis resistance of juvenile Penaeus monodon. J Fish Aquat Sci, 2013; 8(2): 340-54.

Tawut R, Boonsirm W, Kanokpan W. Sulfated galactans from Gracilaria fisheri bind to shrimp haemocyte membrane proteins and stimulate the expression of immune genes. Fish Shellfish Immunology, 2015; 47: 231-38.

Truong-Giang H, Su-Tuen Y, Yong-Chin L, Jeng-Feng S, Jiann-Chu C. White shrimp Litopenaeus vannamei immersed in seawater containing Sargassum hemiphyllum var. chinense powder and its extract showed increased immunity and resistance against Vibrio alginolyticus and white spot syndrome virus. Fish \& Shellfish Immunology, 2011; 31: 286-93.

Usov A.I and Bilan M.I. Fucoidan -sulfated polysaccharides of brown algae. Russian chemical reviews, 2009; 78 (8): 785-99.

Valerie JS, Janet $\mathrm{HB}$, Chris $\mathrm{H}$. Immunostimulation in crustaceans: does it really protect against infection? Fish \& Shellfish Immunology, 2003; 15: 71-90.

Witvrouw M, de Clerq E. Sulfated polysaccharides extracted from sea algae as

potential antiviral drugs. Gen Pharmacol, 1997; 29: 497-511.

Wang J, Zhang Q, Zhang Z, Song H, Li P. Potential antioxidant

and

anticoagulant capacity of low molecular weight fucoidan fractions extracted from Laminaria japonica. International Journal of Biological Macromolecules, 2010; 46: 6-12.

Yu-Yuan C, Jiann-Chu C, Yong-Chin L, Dedi FP, Suwaree K, Chang-Che L, Jen-Fang H, Chyng-Hwa L, Su-Tuen Y. Shrimp that have received carrageenan via immersion and diet exhibit immunocompetence in phagocytosis despite a post-plateau in immune parameters. Fish \& Shellfish Immunology, 2014; 36: 352-66.

Yu-Yuan C, Jiann-Chu C, Yi-Hsuan K, Yong-Chin L, YuHsuan C, Hong-Yi G, Chien-Lun H. Lipopolysaccharide and $\beta$-1,3-glucanbinding protein (LGBP) bind to seaweed polysaccharides and activate the prophenoloxidase system in white shrimpLitopenaeus vannamei. Developmental and Comparative Immunology, 2016; 55: 144-51

Zvyagintseva TN, Shevchenko NM, Popovnich IB. A new procedure for the separation of water-soluble polysaccharides from brown seaweeds. Carbohydrate Research, 1999; 332: 32-9.

Zhang Q, Li F, Wang B, Zhang J. The mitochondrial manganese superoxide dismutase gene in Chinese shrimp Fenneropenaeus chinensis: cloning, distribution and expression. Dev. Comp. Immunol, 2007; 31: 429 40

Zhao DX, Chen LQ, Qin JG, Qin CJ, Zhang H, Wu P, Li EC. Molecular characterization of a cytosolic manganese superoxide dismutase from the Chinese mitten crab Eriocheir sinensis. Genetics and Molecular Research, 2014; 13 (4): 9429-42.

\section{How to cite this article:}

Sinurat E, Saepudin E, Peranginangin R, Hudiyono S. Immunostimulatory activity of brown seaweed-derived fucoidans at different molecular weights and purity levels towards white spot syndrome virus (WSSV) in shrimp Litopenaeus vannamei. J App Pharm Sci, 2016; 6 (10): 082-091. 